\title{
Fetishistic Disorder and Kleptomania
}

\author{
Hanny Soraya, Elmeida Effendy* (iD, Mustafa M. Amin (iD \\ Department of Psychiatry, Faculty of Medicine, Universitas Sumatera Utara, Medan, Indonesia
}

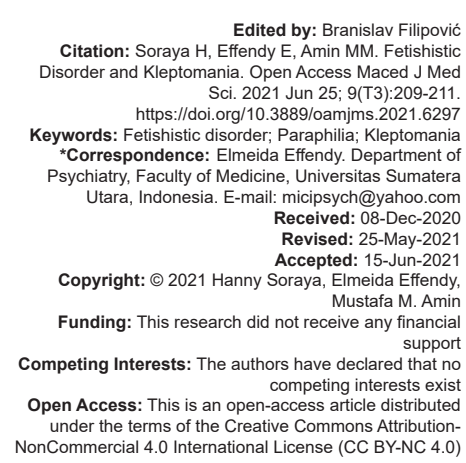

Edited by: Branislav Filipović Effendy E, Amin MM. Fetishistic Citation: Soraya H, Effendy E, Amin MM. Fetishistic
Disorder and Kleptomania. Open Access Maced J Med
Sci. 2021 Jun 25; 9(T3):209-211.
https://doi.org/10.3889/oamjms.2021.6297 Citation: Soraya H, Effendy E, Amin MM. Fetishistic
Disorder and Kleptomania. Open Access Maced J Med
Sci. 2021 Jun 25; 9(T3):209-211.
https://doi.org/10.3889/oamjms.2021.6297 Keywords: Fetishistic disorder; Paraphilia; Kleptomania Psychiatry, Faculty of Medicine, Universitas Sumatera Utara, Indonesia. E-mail: micipsych@yahoo.com
Unchiatro Received: 08-Dec-2020 Revised: 25-May-2021 Accepted: 15-Jun-2021
Copyright: $\odot 2021$ Hanny Soraya, Elmeida Effendy Mustafa M. Amin
Funding: This research did not receive any financial Competing Interests: The authors have declared that no competing interests exist Open Access: This is an open-access article distributed under the terms of the Creative Commons Attributionunder the terms of the Creative Commons Attribution-
NonCommercial 4.0 International License (CC BY-NC 4.0)

\begin{abstract}
BACKGROUND: Recently cases of fetishistic disorder have often occurred in Indonesia. And also usually these cases are often accompanied by other disorders, one of which is kleptomania. Nowadays, Fetishtic disorder becomes one of the psychiatrist's concerns. The psychiatrist's main role is to diagnose, provide care to patients, and reduce personal distress.

AIM: The purpose of this case report is to determine the symptoms and diagnosis of Fetishistic Disorder and Kleptomania.

CASE REPORT: A 26-year-old man, working as a freelance, unmarried, and currently living in a packed neighborhood, arrested by the police and brought for psychiatric examination. The man charged with stealing a lot of clothes from his neighbors. When his house investigated, the police found over 50 pieces of women's clothing and old underwear. CONCLUSION: There has been a lot of controversy about fetishistic disorder and kleptomania and has recently become a concern for psychiatric cases. One of the triggers can occur fetishistic disorder due to sexual harassment. Really do a deeper examination using instruments and perform therapy as quickly as possible. Therapy options that can be carried out include cognitive behavioral therapy, antipsychotic medications, and sensitization therapy.
\end{abstract}

\section{Introduction}

Paraphilic disorders include voyeuristic disorder (spying on others during private activities), exhibitionistic disorder (showing the sexual organs), frotteurism disorder (touching or rubbing against a person who does not approve), sexual masochism disorder (subjected to humiliation, servitude or misery), sexual sadism disorder (inflicting humiliation, servitude, or pain), transvestic disorder pedophilic disorder (sexual fixation on kids), and fetishistic disorder (usage of non-living objects or a highly specific emphasis on non-genital parts of the body) [1], [2].

In certain cases, the "intense and constant" criterion, such as determining individuals who are very old or chronically sick and who do not have "intense" sexual desires of any sort, may be difficult to apply. In such cases, all sexual interests greater than or equal to homophilic sexual interests are characterized by the term paraphilia. The word paraphilia denotes severe and long-lasting sexual concern for phenotypically normal, adult, having a human partner other than sexual interaction in genital stimulation or forging preparations. Specific paraphilias are also usually best characterized as preferential sexual interests than as extreme sexual preferences [1], [3].

One of the paraphilia components is fetishistic disorder. In general terms, "fetishistic disorder" may be defined as the adoration of objects and natural events.
The "Fetish" will be this very object of worship: Worship as divinity itself is not only the reflection or image of divinity, but also a material object or natural occurrence. Initially, these terms apply to religious worship, but they have also extended to other fields in which objects acquire the characteristics of humans, such as fetishistic disorder of the Marxist commodity or Freudian sexual fetishistic disorder.

There are two concepts that are considered the most controversial and contradictory in social science, namely fetish and fetishistic disorders. Since the late nineteenth century, fetish has been emphatically rejected as an anthropological concept; Marcel Mauss was exposed as "a very big misunderstanding." In recent decades, however, there has been an increasing interest in this very confusion, what William Pietz called "the issue of the fetish." This fetish problem refers to some of the fundamental differences from Western thought: Individual and object, behavior and event, subject and object, culture and nature, religion, and economy. The question in contemporary anthropology regarding these differences has undoubtedly brought the fetish subject back into the limelight. From diagnostic and statistical manual of mental disorders (DSM-5), for at least 6 months are the diagnostic criteria of fetishistic, persistent, and extreme sexual excitement from crossdressing, as manifested by fantasies, desires, or behaviors. Fantasies, sexual impulses, or actions in social, educational, or other essential areas of function cause clinically relevant distress or disability [1], [4]. 
Kleptomania is an enigmatic disorder in which a part of its diagnosis criterion is crime (theft). Not surprisingly, this is widely used by defense councils to reduce theft and related crimes, especially for repeat theft perpetrators. In the medical and legal literature, kleptomania has been identified in recent decades, since the early $19^{\text {th }}$ century when the Swiss doctor Mathey, who worked with "madmen," wrote about a strange madness that follows with a tendency without any motive or needs for any object stolen. The tendency to steal remains, but the tendency to steal is greater, trumping the desire to hold back. "The word "kleptomania" was changed to "kleptomania" and was defined by Marc and Esquirol, who was a French doctor, as" a person with an irresistible and uncontrollable urge to steal [1], [5].

\section{Case Report}

A 26-year-old man working as a freelance, unmarried, and currently living in packed neighborhood was arrested by the police and brought psychiatric examination. The man was charged with stealing many clothes from his neighbors. When investigates, the police found over 50 pieces of women's clothing and old underwear.

We found that our patient was appropriately dressed; his facial expression follows his age and seemed to be properly taking care of himself. He did not show any unusual mannerism, and psychomotor activities were average. Our patient was found to be cooperative, and eye contact was present. His speech was appropriate with normal flow and productivity. His tone was neutral, and his choice of diction was fair. He presented an appropriate effect with euthymic mood, and we did not find any delusion or perception disturbance. Our patient was fully attentive throughout the interview.

At first, our patient showed hesitancy about being brought up to the clinic. After a couple of interpersonal counseling, he finally was able to be more reciprocating. Our patient is the only child in the family, his father was a garbage picker, and his mother was a street cleaner. We noted that our patient highlighted that his father was tough and that our patient was often physically abused by his father. On the other hand, his mother ignored him, getting intimidated and had always been exhausted enough after work. Our patient admitted that he began to experience sexual assault from his uncle at the age of 15, in which the uncle rubbed our patient's mother's underwear to our patient's genital, which aroused him and made him want it repeatedly. Few times our patients masturbated, and he admitted that to achieve orgasm, he needed to tie up women's underwear to his genital. To fulfill that, he started stealing his neighbor's underwear until recently. Our patient admitted that he knew very well that his action is wrong, but he had no other way to resist it.

Conduct further examinations and interviews. It was found that the patient had extreme sexual arousal and was manifested by rubbing a woman's underwear against her genitals and one of the initial triggering factors was sexual harassment that she experienced when she was young. Furthermore, completed a questionnaire using the paraphilia scales from Kurt Freund's questionnaire for paraphilia and kleptomania symptom assessment scale for kleptomania and found abnormalities. For the treatments, patients given selective serotonin reuptake inhibitor and cognitive behavior therapy (CBT).

\section{Discussion}

In diagnose fetishistic disorder and kleptomania, there are two separate, distinct features. As in this case, our patient has been stealing women's underwear for nearly two decades to fulfill his sexual fantasy by giving tactile stimulation to his genitals through that specially designed underwear.

Fetishistic disorder is diagnosed when the following criteria from DSM-5:

a. Over a duration of at least 6 months, persistent and extreme sexual arousal, as manifested by fantasies, impulses, or actions, through either the use of non-living objects or a highly focused emphasis on a non-genital body part(s)

b. In social, occupational, or other significant functioning areas, fantasies, sexual impulses, or actions cause clinically significant distress or disability

c. Fetish instruments are not limited to crossdressing pieces of clothing (as in transvestic disorder) or to devices specifically intended for genital tactile stimulation (e.g., vibrator) [1].

As a precursor to the development of paraphilia, more recent theories of paraphilia in the psychoanalytic realm have centered more on object relationships and problematic childhood attachments. As seen in our case, the general belief that a person with paraphilia has experienced sexual exploitation or trauma from childhood is based on the point of view of object relations (developmental outcome of psychoanalytic thinking). Our patient is recovering from his uncle's sexual assault. The explanation is basically that such violence presents itself as subsequent problems in the establishment and preservation of safe, intimate relationships in early relationships with caregivers. Instead, by non-relational means (e.g., through dependence on a fetish object), faux relationships (e.g., exhibitionism, voyeurism, or 
frotteurism), our relationships with partners based on excessive power (e.g., S/M), and the person seeks to fulfill sexual desires [3].

On the other hand, kleptomania is an irresistible urge to steal to the extent that it has been uncontrolled impulse that follows DSM-5 diagnosis criteria, as follows:

1. Recurring inability to resist impulses to steal things that do not need personal use or monetary value

2. Immediately before committing the theft, to increase a sense of tension

3. Pleasure, reward, or relief at the moment of committing the theft

4. The theft is not intended to convey rage or retaliation and is not a reaction to an illusion or hallucination

5. Theft is best explained by behavioral disorder, a manic episode, or antisocial personality disorder [4], [5], [6].

There is a similar connection between fetishistic disorder and kleptomania from a psychodynamic perspective. Some scholars who share this comment argue that fetishistic habits may have much in common with kleptomania and other impulse-control disorders and that kleptomania may be based on fetishistic disorder. Coleman also claimed from these studies that many young kleptomania patients have stolen women's underwear and emphasized that the ecstasy and urge felt when stealing a fetish item leads to sexual arousal orgasm, a disorder that is also seen in people with other fetishistic behaviors. It has drawn attention to the fact that cheating may have a sexual meaning and that it may be a way of masturbation to do a prohibited thing secret. Furthermore, the same author claimed that in some cases, the sexual sense is in the foreground, that such cases are similar to paraphilia, and that the fetish itself is the stolen object. If the emphasis is on the items, then the proper diagnosis might be fetishistic disorder. If the act, but not the object taken, is the subject, then a kleptophilia diagnosis is appropriate [4], [7], [8].

Antipsychotic medication and CBT and frequently supervised sensitization therapy can be an alternative for the treatment of kleptomania and fetish disorder. A limited number of subjects have been tested for pharmacotherapy and psychotherapy, indicating some early promises in the treatment of kleptomania. In the United States, there are no drugs approved by the Food and Drug Administration to treat kleptomania. A variety of effective therapies have been found in case reports investigating the effectiveness of pharmacotherapy for kleptomania, that is, paroxetine, fluvoxamine, escitalopram, a mixture of sertraline and valproic acid, and the stimulant methylphenidate, imipramine in combination with fluoxetine [9].

\section{Conclusion}

There has been a lot of controversy about fetishistic disorder and kleptomania and has recently become a concern for psychiatric cases. One of the triggers can occur fetishistic disorder due to sexual harassment. Really do a deeper examination using instruments and perform therapy as quickly as possible. Therapy options that can be carried out include CBT, antipsychotic medications, and sensitization therapy.

\section{References}

1. American Psychiatric Association. Diagnostic and Statistica Manual of Mental Disorder Edition (DSM-V). Washington, DC: American Psychiatric Publishing; 2013.

2. Långström N, Zucker KJ. Transvestic fetishism in the genera population: prevalence and correlates. J Sex Marital Ther 2005;31(2):87-95. https://doi.org/10.1080/00926230590477934 PMid:15859369

3. Michael W. Paraphilia and fetishism. Family J. 2003;11:315-21.

4. Fatih O, Solmaz T, Ozge C, Dogan Y, Uygur N. Fetishism and kleptomania: A case report in forensic psychiatry. Arch Neuropsychiatry. 2009;46:125-8.

5. Saluja B, Chan LG, Dhaval D. Kleptomania: A case series. Singapore Med J. 2014;55(12):e207-9. https://doi.org/10.11622/ smedj.2014188

PMid:25630329

6. Glenn AL, Johnson AK, Raine A. Antisocial personality disorder: A current review. Curr Psychiatry Rep. 2013;15(12):427. https:// doi.org/10.1007/s11920-013-0427-7

PMid:24249521

7. Sadock BJ, Sadock VA. Concise Textbook of Clinical Psychiatry. Philadelphia: Lippincott Williams \& Wilkins; 2010. 739 p.

8. Ventriglio A, Bhat PS, Torales J, Bhugra D. Sexuality in the $21^{\text {st }}$ century: Leather or rubber? Fetishism explained. Med J Armed Forces India. 2019;75(2):121-4. https://doi.org/10.1016/j. mjafi.2018.09.009

PMid:31065177

9. Grant JE, Odlaug BL. Kleptomania: Clinical characteristics and treatment. Rev Bras Psiquiatr. 2008;30(Suppl 1):11-5.

PMid:17713696 